Dorota Ferenc-Kopeć

\title{
Definicje legalne w dokumentach międzynarodowej ochrony praw czlowieka
}

\section{Wprowadzenie}

Katalog praw i wolności człowieka przyjęty w międzynarodowym systemie praw człowieka jest najczęściej ogólny i wymaga doprecyzowania przez podmiot decyzyjny na etapie stosowania prawa. Wiele przepisów ma charakter otwarty, niejasny, co pozostawia duże możliwości interpretacyjne. Istnienie niezdefiniowanej normatywnie przestrzeni, istniejącej pomiędzy zakresem literalnie pojmowanych praw, wydaje się niezbędne z uwagi na pojawiające się współcześnie nowe źródła zagrożeń. Jak zauważa J. Braciak, w nowej sytuacji organ sięga do wykładni systemowej istniejącego prawa lub wolności, co nierzadko oznacza faktycznie powstanie nowych praw czy tworzenie jakiegoś rodzaju hybrydowej interpretacji praw dotychczasowych. Najczęściej kończy się to na bardzo rozszerzającej interpretacji konkretnych praw i rozmyciu granic samego prawa ${ }^{1}$.

Jednolite rozumienie poszczególnych terminów z zakresu praw człowieka zapewnia państwom-sygnatariuszom danego dokumentu ugruntowana linia orzecznicza przyjęta przez organy sądownictwa międzynarodowego (Europejski Trybunał Praw Człowieka, Trybunał Sprawiedliwości Unii Europejskiej czy Międzynarodowy Trybunał Karny) oraz reguły wypracowane przez międzynarodowe prawo zwyczajowe - w tym wypadku przyjęte znaczenie jest również wiążące dla pozostałych państw i niepaństwowych uczestników stosunków międzynarodowych. Interpretacja niektórych pojęć jest na tyle zróżnicowana i uzależniona od kultury prawnej danego państwa, że przyjęcie przez systemy krajowe jednolitych standardów napotyka na spore trudności ${ }^{2}$.

1 J. Braciak, Prawo do prywatności, Warszawa 2004, s. 207-208.

2 Można tu wskazać na pozostawienie przez Trybunał w Strasburgu państwom dużej swobody w zakresie interpretacji „moralności publicznej” - por. orzeczenie ETPC z 7 grudnia 1976 r., Handyside vs. Wielka Brytania, skarga nr 5493/72. Podobnie w przypadku „obrazy uczuć religijnych" Trybunał uznał, iż w sferze obyczajowej coś może być bardziej akceptowalne w jednym regionie, a mniej w innym $\mathrm{w}$ tym samym państwie. Ocena, jakie środki powinny być w danym 
Jak zaznacza T. Koncewicz, wskazując na szczególną rolę Trybunału Sprawiedliwości w systemie prawa wspólnotowego - instytucja, która decyduje o sposobie wypełnienia tych niezdefiniowanych pojęć jest zmuszona spełniać także funkcję quasi-legislacyjną ${ }^{3}$. Ocenia ona również zasady wykonywania prawa w filarze wspólnotowym. W myśl art. 6 ust. 2 TUE Unia Europejska szanuje prawa podstawowe zagwarantowane w Konwencji o ochronie praw człowieka i podstawowych wolności (EKPC) ${ }^{4}$. Z kolei system strasburski powiązany jest z ogólnym systemem prawa międzynarodowego i nie stanowi w sensie materialnym reżimu samowystarczającego 5 . Teoria interpretacji EKPC nie może zatem pomijać powiązań systemu EKPC z systemem ogólnego prawa międzynarodowego ${ }^{6}$.

Pojawienie się językowych sformułowań w obszarze praw człowieka sprawiło, że stały się one z jednej strony wyrażeniami języka prawnego, z drugiej - przedmiotami badań nauki prawa. W pierwszym przypadku terminy te podlegają zdefiniowaniu w aktach prawa międzynarodowego. $\mathrm{W}$ drugim natomiast do powyższych definicji dochodzi się poprzez uogólnienia szczególnych elementów i cech danego pojęcia.

W konwencjach traktatowych ONZ odnaleźć można kilka definicji legalnych pojęć budzących spore wątpliwości interpretacyjne. Warto zauważyć, że definicje te nie zawsze są rozumiane jednolicie we wszystkich traktatach międzynarodowych. Przenoszenie interpretowanych terminów z dokumentów dotyczących praw człowieka na grunt, przykładowo, międzynarodowego prawa humanitarnego, i na odwrót, musi odpowiadać specyfice tych praw - a to nie zawsze przedkłada się na identyczny definiens. Traktując definicję jako swego rodzaju metanormę ${ }^{7}$, należy uznać jej wiążący charakter przede wszystkim w obrębie danego dokumentu, co nie wyklucza rozszerzenia zakresu jej stosowania przez pozostałe organy sądownictwa międzynarodowego.

W dyskursie argumentacyjnym podstawową rolą definicji jest zagwarantowanie określonej wypowiedzi niezbędnego stopnia precyzyjności ${ }^{8}$. Ogólny charakter wielu praw człowieka wynika z celowego pozostawienia luzów decy-

przypadku zastosowane, zależy przede wszystkim od władz krajowych - por. orzeczenie ETPC z 20 września 1994 r., Otto-Preminger-Institut vs. Austria, skarga nr 13470/87.

3 T. T. Koncewicz, Europejski Trybunat Sprawiedliwości: spróbować zrozumieć, potem krytykować, ,Rzeczpospolita”, 3 listopada 2008, nr 196 (8097).

4 Dz. U. 2004, nr 90, poz. 864/30.

5 Zob. C. Mik, Ochrona praw człowieka w świetle źródet wspótczesnego prawa międzynarodowego, [w:] C. Mik (red.), Prawa człowieka XXI wieku. Wyzwania dla ochrony prawnej, Toruń 2005, s. 66.

6 A. Wiśniewski, Uwagi o interpretacji Europejskiej Konwencji Praw Człowieka, [w:] C. Mik, K. Gałka (red.), Między wyktadniq a tworzeniem prawa. Refleksje na tle orzecznictwa Europejskiego Trybunatu Praw Człowieka i międzynarodowych trybunałów karnych, Torun 2011, s. 33.

7 Przyznanie normatywnego charakteru definicjom legalnym jest $\mathrm{w}$ doktrynie kwestią sporna. Szerzej na ten temat: P. Saługa, Sposoby wyodrębniania definicji legalnych, „Państwo i Prawo” 2008, z. 5.

8 P. Rybiński, K. Zeidler (red.), Leksykon retoryki prawniczej. 100 podstawowych pojęć, Warszawa 2010, s. 32. 
zyjnych dla podmiotów stosujących prawo. Niektóre zwroty wymagały jednak pełnego ujednoznacznienia. Poniżej przedstawiona została charakterystyka kilku pojęć, które zyskały pewną precyzyjność w systemie ONZ i stały się punktem odniesienia dla organów sądownictwa międzynarodowego.

\section{2. „Praca przymusowa lub obowiązkowa”}

W Międzynarodowym Pakcie Praw Obywatelskich i Politycznych (MPPOiP) w art. 8 ust. 3 odnaleźć można definicję negatywną terminu ,praca przymusowa lub obowiązkowa". Prawodawca konwencyjny wyliczył zachowania wyłączone z zakresu przedmiotowego definicji. Zgodnie z postanowieniami Paktu ,praca przymusowa lub obowiązkowa" nie obejmuje:

1) wszelkiej pracy lub świadczeń wymaganych od osób pozbawionych wolności na skutek prawomocnego orzeczenia sądu (w krajach, w których pozbawienie wolności połączone z ciężkimi robotami może być orzeczone jako kara za zbrodnie) lub od osób w okresie warunkowego zwolnienia od takiego pozbawienia wolności;

2) wszelkich świadczeń o charakterze wojskowym, a w krajach uznających uchylanie się od służby wojskowej ze względów religijnych, wszelkich świadczeń na rzecz państwa wymaganych przez ustawę od osób uchylających się;

3) wszelkich świadczeń wymaganych w przypadkach wyjątkowej sytuacji albo klęski zagrażającej życiu lub dobrobytowi społeczeństwa;

4) wszelkiej pracy lub świadczeń stanowiących część normalnych obowiązków obywatelskich ${ }^{9}$.

Podobnie jak MPPOiP, również EKPC nie zawiera pozytywnej definicji „pracy przymusowej lub obowiązkowej”. Odnaleźć ją można natomiast w Konwencji nr 29 Międzynarodowej Organizacji Pracy (MOP) z 1930 r. dotyczącej pracy przymusowej lub obowiązkowej ${ }^{10}$. Do niej odwoływał się również Europejski Trybunał Praw Człowieka ${ }^{11}$. Zgodnie z art. 2 Konwencji MOP zwrot „praca przymusowa lub obowiązkowa” oznacza: „wszelką pracę lub usługi wymagane od jakiejś osoby pod groźbą jakiejkolwiek kary i do których dana osoba nie zgłosiła się dobrowolnie". W sprawie Van der Mussele vs. Belgia Trybunał strasburski uznał, że definicja ta może stanowić punkt wyjścia dla własnej interpretacji art. 4 EKPC. Kryteria, które służą do ograniczania koncepcji pracy przymusowej (cztery akapity ust. 3 art. 2), pomimo ich różnorodności, są oparte na idei użyteczności publicznej i solidarności społecznej ${ }^{12}$. Trybunał

9 Dz. U. 1977, nr 38, poz. 167.

${ }^{10}$ Dz. U. 1959, nr 20, poz. 122.

${ }^{11}$ Zob. np. orzeczenie ETPC z 26 lipca 2005 r., Siliadin $v s$. Francja, skarga nr 73316/01.

${ }^{12}$ Orzeczenie ETPC z 23 listopada 1983 r., Van der Mussele vs. Belgia, skarga nr 8919/80. Analiza orzeczenia zob. M. A. Nowicki, Europejski Trybunat Praw Człowieka. Wybór orzeczeń 2011, Warszawa 2012, s. 202-203. 
nie zgodził się z opinią Komisji, że aby doszło do „pracy przymusowej lub obowiązkowej”, muszą zostać spełnione łącznie dwa warunki, tj. praca musi być wykonywana przez osobę wbrew jej woli oraz obowiązek wykonywania pracy musi być niesprawiedliwy i nieść za sobą element udręki ${ }^{13}$. Uznał, że drugie kryterium nie wynika ani z art. 2 Konwencji MOP, ani z art. 4 EKPC i nie zawiera się w definicji ,pracy przymusowej”.

Poszczególne elementy składające się na istotę terminu "praca przymusowa" - tj. „,wszelka praca lub usługi”, ,jakaś osoba”, „groźba jakiejkolwiek kary”"14, „dobrowolnie" - wymagają dalszego sprecyzowania ${ }^{15}$. Ustalenie znaczenia tych pojęć odbywa się na etapie stosowania prawa, a ich wykładnia ma zasadnicze znaczenie dla interpretacji norm konwencyjnych.

\section{3. „Dyskryminacja rasowa”}

Po raz pierwszy „dyskryminacja rasowa” została zdefiniowana w Międzynarodowej konwencji w sprawie likwidacji wszelkich form dyskryminacji rasowej z 1966 r. Zgodnie z art. 1 wyrażenie to oznacza

wszelkie zróżnicowanie, wykluczenie, ograniczenie lub uprzywilejowanie z powodu rasy, koloru skóry, urodzenia, pochodzenia narodowego lub etnicznego, które ma na celu lub pociąga za sobą przekreślenie bądź uszczuplenie uznania, wykonywania lub korzystania na zasadzie równości z praw człowieka i podstawowych wolności w dziedzinie politycznej, gospodarczej, społecznej i kulturalnej lub w jakiejkolwiek innej dziedzinie życia publicznego ${ }^{16}$.

M. Balcerek podnosi, że pojęcie „dyskryminacji rasowej” w rozumieniu cytowanej Konwencji nie obejmuje wyłącznie dyskryminacji z powodu rasy. Definicja ta jest dużo szersza i z mocy art. 1 obejmuje także kolor skór, urodzenie oraz pochodzenie narodowe lub etniczne. Powoływany autor zwraca również uwage na mylący charakter tytułu traktatu, bowiem - jak zaznacza - „wszelkie formy dyskryminacji rasowej” można rozumieć jako „wszelkie przejawy” tej dyskryminacji. Tymczasem traktat ten dotyczy zwalczania „wszelkich form dyskryminacji rasowej i innej"17.

${ }^{13}$ Iversen vs. Norwegia, skarga nr 1468/62, „Yearbook of the Convention” 1963, t. 6.

${ }^{14} \mathrm{~W}$ opinii Trybunału w pojęciu „kary” mieści się wszelka utrata praw i przywilejów (interpretację tę przyjął za Komitetem Ekspertów MOP) - Abolition of forced labour. General Survey by the Committee of Experts on the Application of Conventions and Recommendations, ILC, 65th Sessions, Geneva 1979, par. 2.1.

${ }^{15} \mathrm{Na}$ temat interpretacji powyższych zwrotów: B. Andrees, Praca przymusowa $i$ handel ludźmi. Podręcznik dla Inspektorów Pracy, Wrocław 2010, s. 4, www.ilo.org/wcmsp5/groups/ public/---ed_norm/---declaration/documents/publication/wcms_144461.pdf (dostęp: 25.04.2014).

${ }^{16}$ Dz. U. 1969, nr 25, poz. 187.

${ }^{17}$ M. Balcerek, Spór gruzińsko-rosyjski przed sqadami międzynarodowymi, [w:] S. Sykuna, J. Zajadło, Bezpieczeństwo międzynarodowe. Szanse i zagrożenia, Gdańsk 2009, s. 11. 
Z kolei F. Felice wyprowadza wprost z Konwencji szersze pojęcie rasy i, jak zaznacza, rasa obejmuje kolor skóry, pochodzenie i przynależność narodową lub etniczną. Termin ,pochodzenie” sugeruje pochodzenie społeczne, takie jak dziedzictwo czy rodowód. Natomiast ,pochodzenie narodowe lub etniczne” obejmuje język, korzenie kulturowe i historyczne. Autor zaznacza, że szerokie pojęcie rasy wyraźnie nie ogranicza się do obiektywnych elementów fizycznych, lecz obejmuje też elementy subiektywne i społeczne ${ }^{18}$.

Pojęcie „pochodzenia rasowego" i „etnicznego” doczekało się również wyjaśnienia w orzecznictwie ETPC, który uznał, że język, religia, obywatelstwo i kultura mogą być nierozerwalnie związane z rasą. Powyższe stanowisko Trybunał zaprezentował w sprawie Timishev vs. Rosja z 2005 r. Zdaniem Trybunału „pochodzenie etniczne” i ,rasa” to

pojęcia wzajemnie ze sobą powiązane i częściowo pokrywające się. Termin „rasa” jest zakorzeniony w koncepcji biologicznej klasyfikacji gatunku ludzkiego na podstawie cech morfologicznych, takich jak kolor skóry czy rysy twarzy, ,pochodzenie etniczne” ma swoją genezę w idei grup społecznych, które łączy wspólna narodowość, przynależność plemienna, religia, język, kultura i tradycje ${ }^{19}$.

Stanowisko to Trybunał ponownie zaakcentował w 2009 r. w sprawie Sejdić i Finci vs. Bośnia i Hercegowina oraz nadmienił, że „dyskryminacja ze względu na pochodzenie etniczne danej osoby stanowi formę dyskryminacji rasowej"20. Powołał się również na zapis Międzynarodowej konwencji w sprawie likwidacji wszelkich form dyskryminacji rasowej oraz stanowisko Rady Europy.

Definicje „dyskryminacji rasowej” znajdują się także w Zaleceniu nr 7 Europejskiej Komisji przeciwko Rasizmowi i Nietolerancji (ECRI). Przy czym:

„bezpośrednia dyskryminacja rasowa” oznacza jakiekolwiek zróżnicowane traktowanie oparte na takich podstawach, jak rasa, kolor skóry, język, religia, obywatelstwo bądź pochodzenie narodowe lub etniczne, które nie ma żadnego obiektywnego i rozsądnego usprawiedliwienia. Zróżnicowane traktowanie nie ma żadnego obiektywnego i rozsądnego usprawiedliwienia, jeżeli nie dąży do osiągnięcia prawnie uzasadnionego celu, albo jeżeli nie ma rozsądnego stosunku proporcjonalności między zastosowanymi środkami i celem, który ma być zrealizowany ${ }^{21}$.

Natomiast „pośrednia dyskryminacja rasowa” w rozumieniu Komisji „oznacza przypadki, gdy pozornie neutralny czynnik, taki jak przepis, kryterium lub praktyka, nie może być tak łatwo przestrzegany lub krzywdzi osoby należące

${ }^{18}$ W. F. Felice, The UN Committee on the elimination of all forms of racial discrimination: Race, and economic and social human rights, „Human Rights Quarterly” 2002, vol. 24, no. 1, s. 205.

${ }^{19}$ Orzeczenie ETPC z 13 grudnia 2005 r., Timishev vs. Rosja, skarga nr 55762/00, par. 55.

${ }^{20}$ Orzeczenie ETPC z 22 grudnia 2009 r., Sejdić i Finci vs. Bośnia i Hercegowina, skarga nr 27996/06 i 34836/06, par. 43.

${ }^{21}$ Zalecenie nr 7 przyjęte 13 grudnia 2002 r. dotyczące ogólnej polityki ECRI w sprawie prawodawstwa krajowego dotyczącego zwalczania rasizmu i dyskryminacji rasowej, CRI Strasbourg (2003)8, s. 5. 
do grupy wyodrębnionej na takiej podstawie, jak rasa, kolor skóry, język, religia, narodowość lub pochodzenie narodowe lub etniczne, chyba że ten czynnik ma obiektywne i racjonalne uzasadnienie" 22 .

„Rasizm” natomiast ECRI uznaje za „przekonanie, że podstawy takie, jak rasa, kolor skóry, język, religia, obywatelstwo albo pochodzenie narodowe lub etniczne usprawiedliwiają pogardę dla osoby albo grupy osób, bądź poczucie wyższości osoby albo grupy osób" 23 .

Zakres stosowania powyższych definicji Komisja określiła explicite w samym tekście prawnym, umieszczając je w części zatytułowanej „Kluczowe elementy w prawodawstwie krajowym dotyczącym zwalczania rasizmu i dyskryminacji rasowej”. Na marginesie warto zauważyć, że w Zaleceniu ECRI odrzuca wszelkie teorie oparte na istnieniu różnych „ras”, uznając, iż wszyscy ludzie należą do tego samego gatunku. W dokumencie pojęcie to używane jest $\mathrm{w}$ celu zapewnienia, że te osoby, które są ogólnie i błędnie postrzegane jako należące do „innej rasy” nie są wyłączone spod ochrony prawnej ${ }^{24}$.

\section{4. „Tortury” oraz ,inne okrutne, nieludzkie lub poniżające traktowanie albo karanie"}

W ciągu ostatnich kilkudziesięciu lat pojęcie „tortury” zyskało znaczną moc normatywną $\mathrm{w}$ praktyce międzynarodowej. Po raz pierwszy przestępstwo tortur expressis verbis zostało zdefiniowane w Deklaracji Zgromadzenia Ogólnego ONZ o ochronie wszystkich osób przed poddawaniem ich torturom i innemu okrutnemu, nieludzkiemu lub poniżającemu traktowaniu lub karaniu. Zgodnie z art. 1 ust. 1 Deklaracji „tortury” oznaczają

wszelkie działanie powodujące dotkliwy ból lub cierpienie, zarówno fizyczne jak i psychiczne, które jest umyślnie zadane osobie przez funkcjonariusza publicznego lub za jego namową, dla takich celów, jak uzyskanie od tej lub trzeciej osoby informacji lub przyznania się, ukarania jej za czyn, który popełniła lub o popełnienie którego jest podejrzana, zastraszenie jej lub innych osób. Nie obejmuje to nieodłącznego lub przypadkowego bólu lub cierpienia wynikającego tylko ze stosowania sankcji prawnych w stopniu pozostającym w zgodności z Podstawowymi Regułami Postępowania z Więźniami ${ }^{25}$.

B. Nowak wskazuje na trzy kryteria tej definicji, wyróżniające „tortury” spośród innych praktyk powodujących psychiczne i fizyczne cierpienie człowieka: 1) motyw zadawania tortur, którym jest wydobycie określonych zeznań,

${ }^{22}$ Ibidem.

${ }^{23}$ Ibidem.

${ }^{24}$ Ibidem, s. 5, przyp. 1.

${ }^{25}$ Rezolucja Zgromadzenia Ogólnego ONZ 3452(XXX) z 9 grudnia 1975 r., tekst na stronie internetowej: http://textus.diplomacy.edu/Thina/txGetXDoc.asp?IDconv=1277 (dostęp: 25.04.2014). 
realizowane poprzez zastraszenie albo chęć ukarania ewentualnego sprawcy; tortury według definicji legalnej Deklaracji są czynami umyślnymi; 2) stopień dolegliwości, którego przekroczenie stanowi o zakwalifikowaniu danego czynu jako tortury; 3) stosowanie tortur przez przedstawiciela władzy państwowej lub $\mathrm{z}$ jego namowy ${ }^{26}$.

Do definicji „tortur” zawartej w Deklaracji z 1975 r. odsyłały inne dokumenty tworzone w ramach systemu ONZ aż do 1984 r. $^{27}$, kiedy to powstała Konwencja w sprawie zakazu stosowania tortur oraz innego okrutnego, nieludzkiego lub poniżającego traktowania albo karania. Zdefiniowała ona znacznie szerzej „tortury”, uznając, iż jest to

każde działanie, którym jakiejkolwiek osobie umyślnie zadaje się ostry ból lub cierpienie, fizyczne bądź psychiczne, w celu uzyskania od niej lub od osoby trzeciej informacji lub wyznania, w celu ukarania jej za czyn popełniony przez nią lub osobę trzecią albo o którego dokonanie jest ona podejrzana, a także w celu zastraszenia lub wywarcia nacisku na nią lub osobę trzecią albo w jakimkolwiek innym celu wynikającym z wszelkiej formy dyskryminacji, gdy taki ból lub cierpienie powodowane są przez funkcjonariusza państwowego lub inną osobę występującą w charakterze urzędowym lub z ich polecenia albo za wyraźną lub milczącą zgodą. Określenie to nie obejmuje bólu lub cierpienia wynikających jedynie ze zgodnych z prawem sankcji, nieodłącznie związanych z tymi sankcjami lub wywołanych przez nie przypadkowo ${ }^{28}$.

W tak zakrojonej definicji wyróżnić można kilka istotnych elementów, których wystapienie pozwala zaklasyfikować dane zachowanie jako „tortury”: 1) każde działanie, a także zaniechanie, powodujące ostry ból lub cierpienie psychiczne lub fizyczne; 2) działanie to jest celowe, zaś celem jest uzyskanie informacji lub wyznania od ofiary lub osoby trzeciej, ukaranie ofiary za czyn popełniony przez nią lub osobę trzecią albo o którego dokonanie jest ona podejrzana, zastraszenie lub wywarcie nacisku na ofiarę lub osobę trzecią albo w jakimkolwiek innym celu wynikającym z wszelkiej formy dyskryminacji; 3) ból lub cierpienie są zadawane umyślnie; 4) popełniane są przez osoby działające w charakterze publicznym lub z ich polecenia albo za wyraźną lub milczącą zgodą; 5) drastyczność bólu lub cierpienia zaznacza przymiotnik „ostry”.

Brak jednolitego rozumienia terminu „tortury” na gruncie prawa międzynarodowego potwierdzają dwie kolejne definicje legalne tego pojęcia. Jedna zawarta jest w Międzyamerykańskiej konwencji w sprawie zapobiegania torturom i karania za ich stosowanie z 1985 r., druga w Statucie Międzynarodowego Trybunału Karnego z 1998 r. Pierwszy z dokumentów nie wprowadza do definicji ,tortur”

${ }^{26}$ B. Nowak, Zakaz tortur, nieludzkiego, poniżajacego traktowania lub karania, [w:] A. Florczak, B. Bolechow (red.), Prawa i wolności I i II generacji, Toruń 2006, s. 70.

${ }^{27}$ Zob. Code of conduct for Law Enforcement Officials adopted by General Assembly resolution 34/169 of 17.12.1979 (A/RES/34/16); Principles of Medical Ethics resolution 37/194 of 18.12.1982 (A/RES/37/194).

${ }^{28}$ Dz. U. 1989, nr 63, poz. 378. 
progu intensywności bólu lub cierpienia. Wskazuje natomiast na użycie wobec osoby metod mających na celu zatarcie osobowości ofiary bądź zmierzających do obniżenia jej zdolności fizycznych lub psychicznych, nawet jeśli nie powodują bólu fizycznego lub cierpienia psychicznego (art. 2) ${ }^{29}$. Drugi dokument - szerszy co do zakresu stosowania - w art. 7 ust. 1 pkt e definiuje „tortury” jako

celowe zadawanie dotkliwego bólu lub cierpienia, fizycznego bądź psychicznego, jakiejkolwiek osobie będącej pod opieką lub pod kontrolą oskarżonego; termin ten nie obejmuje bólu i cierpienia wynikających jedynie ze zgodnych z prawem sankcji, nieodłącznie związanych z tymi sankcjami lub wywołanych przez nie przypadkowo ${ }^{30}$.

Tak rozumiane „tortury” mogą stanowić zbrodnię wojenną lub zbrodnię przeciwko ludzkości. Statut nie wymienia celu zadawania bólu lub cierpienia. Szersze jest w nim, w porównaniu do postanowień wcześniejszych aktów, określenie sprawcy tortur - nie wprowadza bowiem wymogu, aby działania te były dokonywane przez funkcjonariusza państwowego lub inną osobę działającą w imieniu państwa.

MTK w sprawie Prokurator vs. Z. Delalić, Z. Mucić, H. Delić, E. Landžo przytoczył definicję „tortur” z Konwencji o zakazie stosowania tortur z 1984 r. oraz Międzyamerykańskiej konwencji w sprawie zapobiegania torturom i karania za ich stosowanie z 1985 r. W sprawie Prokurator vs. D. Kunarac, R. Kovač i Z. Vuković Izba Orzekająca odwołała się również do decyzji Komitetu Praw Człowieka i orzecznictwa Europejskiej Komisji i Trybunału Praw Człowieka. Uznała definicję ,tortur” zawartą w Konwencji ONZ z 1984 r. wyłącznie za pomoc interpretacyjną ${ }^{31}$.

Od pojęcia „tortury” należy rozgraniczyć pojęcie „okrutnego, nieludzkiego lub poniżającego traktowania albo karania". Zostało ono zdefiniowane w sposób negatywny w art. 16 Konwencji ONZ jako „,inne akty okrutnego, nieludzkiego lub poniżającego traktowania albo karania, nie określone w artykule pierwszym, gdy akty takie dokonywane są przez funkcjonariusza państwowego lub inną osobę występującą w charakterze urzędowym, na skutek ich polecenia lub za ich wyraźną lub milczącą zgodą". Tak określone definiendum doczekało się wykładni w orzecznictwie ETPC.

W sprawie Irlandia $v s$. Wielka Brytania Trybunał wziął pod uwagę różnicę zawartą w art. 3 EKPC pomiędzy pojęciem ,tortury” a pojęciem ,inne nieludzkie lub poniżające traktowanie". W ocenie Trybunału różnica ta wynika głównie

${ }^{29}$ Inter-American Convention to Prevent and Punish Torture, 12.09.1985, O.A.S.T.S. 1985 no. 67 A-51. Tekst konwencji: www.oas.org/juridico/English/Treaties/a-51.html (dostęp: 25.04.2014).

${ }^{30}$ Dz. U. 2003, nr 78, poz. 708.

${ }^{31}$ Prokurator vs. D. Kunarac, R. Kovač i Z. Vuković, Izba Orzekająca 2001, par. 495-496. Szerzej na ten temat zob. A. Szpak, Ewolucja definicji tortur w orzecznictwie Międzynarodowego Trybunału Karnego ds. Zbrodni w Byłej Jugosławii, „Problemy Współczesnego Prawa Międzynarodowego, Europejskiego i Porównawczego" 2009, t. VIII, z. 2, s. 153 i n. 
ze stopnia okrucieństwa i intensywności zadawanego cierpienia ${ }^{32}$. Innymi słowy: uznał, że decydującym kryterium wyróżniającym „tortury” od innych form „nieludzkiego lub poniżającego traktowania" jest nasilenie cierpień, a nie - jak zakładała Komisja - cel działania (uzyskanie zeznania i wymuszenie przyznania się).

W podobnym tonie wypowiedział się Komitet Przeciwko Torturom w sprawie Jovica Dimitrov vs. Serbia i Czarnogóra w $2005 \mathrm{r}^{33}$ Klasyfikując zachowanie funkcjonariuszy publicznych jako „tortury”, organ ten wziął pod uwagę intensywność zadawanego bólu i cierpienia. Jedynym przypadkiem, w którym Komitet stwierdził naruszenie art. 16 Konwencji była sprawa Hajrizi Dzemajl i in. vs. Jugosławia ${ }^{34}$. Skarżący powołali się w skardze na podobne sprawy rozpatrywane przez Trybunał strasburski. Komitet wziął pod uwagę inne kryteria niż ETPC. Za priorytetowe uznał zbadanie celu działania, mniejszą wagę przykładając do kryterium intensywności cierpienia ${ }^{35}$.

Na kontrowersyjność w interpretacji ,tortur” oraz frazy „okrutne, nieludzkie oraz poniżające traktowanie albo karanie" zwraca się również uwagę w literaturze przedmiotu ${ }^{36}$.

\section{5. „Dyskryminacja kobiet”}

„Dyskryminacja kobiet” stanowi przykład drugiej definicji legalnej dotyczącej problematyki dyskryminacyjnej w międzynarodowym systemie ochrony praw człowieka. Konwencja w sprawie likwidacji wszelkich form dyskryminacji kobiet z 1979 r. definiuje to pojęcie jako

wszelkie zróżnicowanie, wyłączenie lub ograniczenie ze względu na płeć, które powoduje lub ma na celu uszczuplenie albo uniemożliwienie kobietom, niezależnie od ich stanu cywilnego, przyznania, realizacji bądź korzystania na równi z mężczyznami z praw człowieka oraz podstawowych wolności w dziedzinach życia politycznego, gospodarczego, społecznego, kulturalnego, obywatelskiego i innych ${ }^{37}$.

M. Półtorak podkreśla, że cytowana definicja wzorowana była na definicjach „dyskryminacji” zawartych w Konwencji UNESCO w sprawie eliminacji dyskryminacji w dziedzinie oświaty z 1960 r. ${ }^{38}$ oraz Konwencji w sprawie eliminacji

\footnotetext{
${ }^{32}$ Orzeczenie ETPC z 18 stycznia 1978 r., Irlandia vs. Wielka Brytania, skarga nr 5310/71, par. 167.

${ }^{33}$ Jovica Dimitrov vs. Serbia i Czarnogóra, Communication no. 171/2000, U.N. Doc. CAT/C/34/171/2000.

${ }^{34}$ Hajrizi Dzemajl i in. vs. Jugosławia, Communication no. 161/2000, U.N. Doc. CAT/ C/29/D/161/2000, par. 9.2 .

${ }^{35}$ Ciekawy artykuł na ten temat: M. Nowak, What practices constitute torture? US and UN standards, „Human Rights Quarterly” 2006, vol. 28, no. 4, s. 809-841.

${ }^{36}$ Zob. M. Freeman, Prawa człowieka, Warszawa 2007, s. 48. J. Zajadło zaznacza praktykę rządu USA polegającą na odchodzeniu od literalnego brzmienia definicji ,tortur" $\mathrm{z}$ art. 1 Konwencji ONZ. Zob. idem, Po co prawnikom filozofia prawa, Warszawa 2008, s. 41 i n.

${ }^{37}$ Dz. U. 1982, nr 10, poz. 71.

${ }^{38}$ Dz. U. 1964, nr 40, poz. 268.
} 
wszelkich form dyskryminacji rasowej ${ }^{39}$. Uprzednio dyskryminację ze względu m.in. na płeć zdefiniowała Konwencja nr 111 Międzynarodowej Organizacji Pracy dotycząca dyskryminacji w zakresie zatrudnienia i wykonywania zawodu z 1958 r. Zgodnie z jej art. 1 „dyskryminacja” oznacza

wszelkie rozróżnienie, wyłączenie lub uprzywilejowanie oparte na rasie, kolorze skóry, płci, religii, poglądach politycznych, pochodzeniu narodowym lub społecznym, które powoduje zniweczenie albo naruszenie równości szans lub traktowania w zakresie zatrudnienia lub wykonywania zawodu ${ }^{40}$.

Definicja przyjęta w Konwencji z 1979 r. jest kompletna, szeroka i obejmuje nie tylko bezpośrednie rodzaje dyskryminacji - często łatwe do stwierdzenia - lecz także formy trudniejsze do zdefiniowania, formalnie neutralne pod względem płci, ale które w praktyce mogą mieć negatywny wpływ na sytuację kobiet. W przeciwieństwie do innych definicji, które odnoszą się do „dyskryminacji” w oparciu o płeć, art. 1 Konwencji (jak i sama Konwencja) zawiera szczegółowe wyjaśnienia znaczenia dyskryminacji wobec kobiet. $\mathrm{Na}$ ten przepis powołują się w swoich dokumentach inne wyspecjalizowane organy prawne. Jest on systematycznie cytowany przez organy sądownictwa międzynarodowego ${ }^{41}$.

Na marginesie warto zauważyć, że do form dyskryminacji kobiet zaliczona została w kontekście de iure i de facto przemoc wobec kobiet, w tym przemoc domowa ${ }^{42}$.

\section{Pozostale definicje}

Do pozostałych definicji legalnych występujących w konwencjach międzynarodowej ochrony praw człowieka należy zaliczyć m.in. definicje „uchodźcy”, „dziecka” i „wymuszonego zaginięcia”. Z uwagi na ramy objętościowe niniejszego opracowania i szeroki zakres omawianych zagadnień są one jedynie przyczynkiem do dalszych prac z tego zakresu.

${ }^{39}$ M. Półtorak, Zakaz dyskryminacji w prawie wspólnotowym, „De Doctrina Europea. Roczniki Instytutu Europeistyki” [Sosnowiec] 2009, s. 5.

${ }^{40}$ Dz. U. 1961, nr 42, poz. 218.

${ }^{41}$ Zob. orzeczenie ETPC z 9 czerwca 2009 r., Opuz vs. Turcja, skarga nr 33401/02; orzeczenie ETPC z 8 listopada 2011 r., V.C. vs. Słowacja, skarga nr 18968/07; Maria da Penha vs. Brazylia, Case 12.051, Report no. 54/01, OEA/Ser.L/V/II.111 Doc. 20 rev. at 704 (2000).

${ }^{42}$ Zob. Committee on the Elimination of Discrimination against Women (CEDAW), General Recommendation no. 19 (1992) on Violence against Women, pkt 6; Commission on Human Rights Resolution 2003/45, Elimination of Violence against Women; The Inter-American Convention on the Prevention, Punishment, and Eradication of Violence against Women - „Convention of Belém do Pará", 9.06.1994. 
Konwencja o Prawach Dziecka, przyjęta przez Zgromadzenie Ogólne Narodów Zjednoczonych dnia 20 listopada 1989 r., w art. 1 definiuje „dziecko” jako „każdą istotę ludzką w wieku poniżej osiemnastu lat, chyba że zgodnie z prawem odnoszącym się do dziecka uzyska ono wcześniej pełnoletność"43. Jak zauważa T. Smyczyński, treść tego przepisu jest kompromisem między stanowiskiem tych, którzy domagali się wyraźnego sformułowania, że dzieckiem jest się od poczęcia a przedstawicielami tych państw, którzy bronią legalności przerywania ciąży ${ }^{44}$.

Definicja nie określa dolnej granicy wiekowej, od której można mówić o istocie ludzkiej jako o „dziecku”, pozostawiając w tym zakresie swobodę dla państwa ratyfikującego Konwencję. W uwagach Międzynarodowego Komitetu Czerwonego Krzyża do projektu Konwencji zaznaczono, że taka koncepcja definicji ,dziecka" wydaje się mądra i ułatwi powszechne stosowanie Konwencji, niezależnie od kultur lokalnych ${ }^{45}$. Polski prawodawca w ustawie o Rzeczniku Praw Dziecka uznaje za „dziecko" istotę od momentu poczęcia ${ }^{46}$.

Kolejne z pojęć konwencyjnych - pojęcie „uchodźcy” - zostało sprecyzowane w Konwencji dotyczącej statusu uchodźców z 1951 r. Zgodnie z art. 1 ust. 2 tego dokumentu oznacza ono

osobę, która na skutek uzasadnionej obawy przed prześladowaniem z powodu swojej rasy, religii, narodowości, przynależności do określonej grupy społecznej lub z powodu przekonań politycznych przebywa poza granicami państwa, którego jest obywatelem, i nie może lub nie chce z powodu tych obaw korzystać z ochrony tego państwa, albo która nie ma żadnego obywatelstwa i znajdując się na skutek podobnych zdarzeń poza państwem swojego dawnego stałego zamieszkania, nie może lub nie chce z powodu tych obaw powrócić do tego państwa ${ }^{47}$.

W definicji tej pojawiają się zwroty niedookreślone, budzące spore wątpliwości interpretacyjne (np. zwrot „uzasadniona obawa przed prześladowaniem”).

W systemie europejskim na mocy dyrektywy kwalifikacyjnej po raz pierwszy przyjęto regionalną definicję ochrony uzupełniającej jako formy subsydiarnej do statusu uchodźcy. Ochrona taka przewidziana została w art. 15 dyrektywy, zgodnie z którym „osoba kwalifikująca się do ochrony uzupełniającej” oznacza obywatela państwa trzeciego albo bezpaństwowca, który nie kwalifikuje się jako uchodźca, lecz w odniesieniu do którego istnieją istotne podstawy, aby uznać, iż jeśli taka osoba wróci do swojego kraju pochodzenia, a w przypadku bezpaństwowca - do państwa poprzedniego miejsca stałego pobytu, może napotkać rzeczywiste ryzyko doznania poważnej krzywdy przez: 1) orzeczenie kary śmierci

${ }^{43}$ Dz. U. 1991, nr 120, poz. 526.

${ }^{44}$ T. Smyczyński, Pojęcie dziecka i jego podmiotowość, [w:] idem (red.), Konwencja o Prawach Dziecka. Analiza i wykładnia, Poznań 1999, s. 40.

${ }^{45}$ Article 1 for: Legislative History of the Convention on the Rights of the Child (1978-1989), UNICEF UN-SEC-HR/1996/SER.1/ARTICLE.01.

${ }^{46}$ Dz. U. 2000, nr 6, poz. 69.

${ }^{47}$ Dz. U. 1991, nr 119, poz. 515 i 517. 
lub wykonanie egzekucji; 2) tortury, nieludzkie lub poniżające traktowanie albo karanie; 3) poważne i zindywidualizowane zagrożenie dla życia lub zdrowia, wynikające $\mathrm{z}$ powszechnego stosowania przemocy wobec ludności cywilnej w sytuacji międzynarodowego lub wewnętrznego konfliktu zbrojnego, i ze względu na to ryzyko nie może lub nie chce korzystać z ochrony kraju pochodzenia ${ }^{48}$.

Ostatni z terminów - „wymuszone zaginięcie” - zgodnie z Międzynarodową konwencją o ochronie wszystkich osób przed wymuszonym zaginięciem (ICCPED) z 2006 r. oznacza

zatrzymanie, areszt, porwanie lub inną formę pozbawienia wolności przez funkcjonariuszy państwa lub osoby lub grupy osób działających z upoważnienia, z pomocą lub za wiedzą państwa, kiedy towarzyszy temu odmowa uznania faktu pozbawienia wolności lub ukrywanie losu lub miejsca pobytu osoby zaginionej, co lokalizuje tę osobę poza ochroną prawa ${ }^{49}$.

Brak definicji legalnych wielu pojęć w systemie prawa międzynarodowego nie stanowi przeszkody dla rozwoju ochrony poszczególnych praw. Problem pojawia się, gdy to samo pojęcie jest odmiennie definiowane w różnych dokumentach. Część definicji z zakresu praw człowieka jest nieostra i ma błędny zakres. Dla interpretacji norm konwencyjnych istotna staje się wykładnia przyjmowana przez organy stosujące prawo, która powinna być zgodna z fundamentalnymi zasadami interpretacyjnymi, zwłaszcza z zasadą in dubio pro dignitate.

${ }^{48}$ Dyrektywa Rady 2004/83/WE z dnia 29 kwietnia 2004 r. w sprawie minimalnych norm dla kwalifikacji i statusu obywateli państw trzecich lub bezpaństwowców jako uchodźców lub jako osoby, które z innych względów potrzebują międzynarodowej ochrony oraz zawartości przyznawanej ochrony, 2004/83/WE, Dz. Urz. UE L 304 z 30 września 2004 r.

${ }^{49}$ International Convention for the Protection of All Persons from Enforced Disappearance, New York 20.12.2006, Doc. A/61/488, art. 2. 